\title{
Dampak Pemberian Biskuit pada Ibu Hamil Berisiko Kekurangan Energi Kronis terhadap Kadar Hemoglobin
}

\author{
Sairuroh ${ }^{1}$, Mohammad Zen Rahfiludin ${ }^{2}$, Martha Irene Kartasurya ${ }^{2}$ \\ ${ }^{1}$ Alumni Magister Ilmu Kesehatan Masyarakat Universitas Diponegoro, Email: sairurohefendi@gmail.com \\ ${ }^{2}$ Fakultas Kesehatan Masyarakat, Universitas Diponegoro
}

Info Artikel : Diterima 21 Januari 2019 ; Disetujui 2 Maret 2019 ; Publikasi 29 April 2019

\begin{abstract}
ABSTRAK
Latar belakang: Pada 2016 penyebab Angka Kematian Bayi tertinggi di Kabupaten Tegal adalah Berat Badan Lahir Rendah (BBLR). Salah satu penyebab BBLR adalah kekurangan energi kronis (KEK) pada ibu hamil. Program pemberian makanan tambahan (PMT) pada ibu hamil merupakan upaya untuk mencegah BBLR. Penelitian ini bertujuan untuk menganalisis pengaruh PMT pada ibu hamil berisiko KEK terhadap kadar hemoglobin saat akan melahirkan.

Metode: Desain penelitian kuasi eksperimen. Subyek penelitian 51 ibu hamil berisiko KEK (Lingkar Lengan Atas $<23,5 \mathrm{~cm}$ ) dari keluarga miskin (perlakuan) yang mendapat PMT dan 51 ibu hamil berisiko KEK non keluarga miskin sebagai kontrol. PMT berupa 5 keping biskuit/hari dari Kemenkes RI yang diberikan selama 90 hari. Pengumpulan data dengan wawancara terstruktur dan pengukuran kadar Hemoglobin yang dilakukan sebelum dan sesudah perlakuan. Analisis data menggunakan General Linear Model.

Hasil: Peningkatan kadar hemoglobin kelompok perlakuan $(1,29 \pm 0,76 \mathrm{~g} / \mathrm{dl})$ lebih tinggi $(\mathrm{p}=0,032)$ daripada kelompok kontrol $(0,97 \pm 0,75 \mathrm{~g} / \mathrm{dl})$. Tingkat kecukupan energi (TKE) kelompok kontrol $(67,6 \pm 10,7 \%)$ lebih tinggi ( $\mathrm{p}=0,003)$ dari TKE kelompok perlakuan $(60,4 \pm 13,3 \%)$, Tingkat kecukupan protein (TKP) kelompok perlakuan $(96,4 \pm 30,4 \%)$ lebih tinggi $(\mathrm{p}=0,015)$ dari pada kelompok kontrol $(83,6 \pm 20,97 \%)$. Setelah dikontrol TKE, PMT biskuit meningkatkan kadar hemoglobin ibu $(\mathrm{p}=0,005)$.

Simpulan: PMT biskuit pada ibu hamil berisiko KEK meningkatkan kadar Hemoglobin pada saat akan melahirkan.
\end{abstract}

Kata kunci : Pemberian Makanan Tambahan, Biskuit, Kadar Hemoglobin, Ibu hamil, Risiko KEK

\section{ABSTRACT}

Title: Effect of Biscuit Supplementation for Pregnant women on Hemoglobin Levels

Background: In 2016, the highest cause of infant mortality in Tegal Regency was low birth weight (LBW). One of the causes of $L B W$ was protein energy malnutrition (PEM) in pregnant mothers. The complementary feeding program (CFP) to pregnant mothers is an effort to resolve the PEM problem. This research aimed to analyze the effect of CFP on hemoglobin levels of pregnant women.

Method: The subjects of this quasy-experiment were 51 pregnant women at risk of PEM $(M U A C<23.5 \mathrm{~cm})$ from poor families who got CFP, and 51 pregnant women at risk of PEM, who were not poor as control. The CFP was in the form of 5 pieces of biscuits from The Indonesian Ministry of Health, given daily in 90 days. Data were collected by structured interviews. Hemoglobin levels were measured before and after intervention. The analysis used General Linear Model.

Result: After the intervention, the increase of hemoglobin levels in the treatment group $(1.29 \pm 0.76 \mathrm{~g} / \mathrm{dl})$ was higher $(p=0.032)$ than the control group $(0.97 \pm 0.75 \mathrm{~g} / \mathrm{dl})$. The energy sufficiency levels (ESL) of control group $(67.6 \pm 10.7 \%)$ was higher $(p=0.003)$ than the treatment group $(60.4 \pm 13.3 \%)$. The protein sufficiency levels $(P S L)$ in the treatment group $(96.4 \pm 30.4 \%)$ was higher $(p=0.015)$ than the control group $(83.6 \pm 20.97 \%)$. After controlled by ESL, complementary feeding program increased the hemoglobin levels at birth $(p=0.005)$.

Conclusion: Biscuit feeding program for 90 days increased the hemoglobin level of pregnant women who were at risk of PEM

Keywords: Food supplementation, biscuit, Hemoglobin levels, pregnant women, Protein Energy Malnutrition. 


\section{PENDAHULUAN}

Angka Kematian Bayi (AKB) di Kabupaten Tegal meningkat dari 9,63 per 1000 kelahiran hidup (KH) pada tahun 2015 menjadi 9,73 per $100 \mathrm{KH}$ pada tahun 2015. Penyebab AKB di Kabupaten Tegal pada tahun 2016 tertinggi disebabkan karena BBLR sebanyak 30,1\%. ${ }^{1}$

Salah satu faktor risiko yang berkontribusi besar terhadap kematian bayi terutama pada masa perinatal yaitu bayi berat lahir rendah (BBLR) yang disebabkan oleh ibu hamil kekurangan energi kronis $(\mathrm{KEK}){ }^{2}$ Kekurangan gizi pada ibu hamil akan menimbulkan masalah, baik pada ibu maupun janin yang dikandungnya, antara lain: anemia, perdarahan dan berat badan ibu tidak bertambah secara normal. Kurang gizi juga dapat mengakibatkan persalinan sulit dan lama, prematur, perdarahan setelah persalinan, serta dapat mempengaruhi pertumbuhan janin, menimbulkan keguguran, cacat bawaan dan berat bayi lahir rendah. ${ }^{2}$

Salah satu upaya yang dapat dilakukan untuk mempertahankan dan meningkatkan status gizi ibu hamil yaitu dengan memberikan makanan tambahan. ${ }^{3}$ Program PMT bagi ibu hamil bertujuan untuk menambah asupan gizi ibu hamil sehingga kebutuhan gizi ibu hamil dapat terpenuhi. Jenis makanan tambahan yang diberikan adalah Biskuit Sandwich. Biskuit ini terbuat dari terigu, lemak nabati tanpa hidrogenasi, gula, susu, telur, kacangkacangan, buah kering, diperkaya dengan vitamin dan mineral, dengan atau tanpa penambahan bahan tambahan pangan (BTP) sesuai dengan ketentuan yang berlaku. ${ }^{4}$ Satu bungkus biskuit sandwich berisi 5 keping @ 20 g, setiap 100 g mengandung energi $500 \mathrm{kkal}, 15 \mathrm{~g}$ protein dan $25 \mathrm{~g}$ lemak. Energi dari lemak sebesar $230 \mathrm{kkal} .^{5}$

Jumlah ibu hamil di Kabupaten Tegal pada tahun 2016 berjumlah 29.453 bumil, 9.850 bumil $(33,4 \%)$ tergolong risiko tinggi, yang terdiri dari faktor usia $(39,5 \%)$ dan berisiko KEK dengan Lingkar Lengan Atas <23,5 cm (18,71\%).

Persentase ibu hamil berisiko KEK tertinggi terdapat di Puskesmas Pagerbarang $(26,95 \%)$ dan terendah terdapat di puskesmas Kaladawa(0,9\%). Salah satu upaya untuk meningkatkan status gizi ibu selama hamil adalah Program Pemberian Makanan Tambahan (PMT) pemulihan. ${ }^{6}$ PMT pemulihan bagi ibu hamil dimaksudkan sebagai tambahan, bukan sebagai makanan pengganti sehari-hari. Selain PMT pemulihan pada ibu hamil, juga dilakukan penyuluhan pada ibu hamil melalui kelas ibu hamil dan ANC terpadu. ${ }^{7}$

Program Pemberian makanan tambahan bagi ibu hamil berisiko KEK di Kabupaten Tegal dilakukan pada ibu hamil dari keluarga miskin, dengan memberikan 5 keping biskuit per hari dengan lama pemberian selama 90 hari. $^{8}$
Ingin diketahui apakah Program PMT yang dilakukan di Kabupaten Tegal mempunyai dampak terhadap Kadar Hemoglobin ibu.

\section{METODE PENELITIAN}

Variabel bebas dalam penelitian ini adalah pemberian makanan tambahan pada ibu hamil KEK, Variabel terikat kadar hemoglobin ibu, sedangkan variabel perancu yaitu asupan gizi berupa tingkat kecukupan energi (TKE) dan Tingkat Kecukupan Protein (TKP), riwayat penyakit ibu. Jenis penelitian kuantitatif, Penelitian ini merupakan Penelitian esksperimen semu (quasi eksperimen). ${ }^{9}$ Satu kelompok perlakuan sebagai kelompok yang mendapat PMT dan satu kelompok kontrol sebagai kelompok yang tidak mendapat PMT. ${ }^{10}$

Populasi dalam penelitian ini adalah seluruh ibu hamil KEK di Kabupaten Tegal pada tahun 2016 . Penelitian ini dilaksanakan di tujuh Puskesmas di Kabupaten Tegal yaitu di Puskesmas Slawi, Adiwerna tergolong kategori Puskesmas perkotaan dan Puskesmas Kambangan, Pagerbarang, Dukuhwaru, Lebaksiu dan Margasari tergolong kategori Puskesmas pedesaan. ${ }^{11}$

Jumlah responden yang menjadi subjek penelitian sebanyak $102 \mathrm{ibu}$ hamil dengan lingkar lengan atas $<23,5 \mathrm{~cm}$, yang terbagi menjadi dua kelompok yaitu kelompok perlakuan adalah $51 \mathrm{ibu}$ hamil KEK dari keluraga miskin yang mendapat kan program PMT dari Kemenkes berupa biskuit sandwich selama 90 hari yang di konsumsi @ 5 keping perhari dan kelompok kontrol yaitu ibu hamil KEK dari keluarga non miskin yang tidak mendapat PMT. ${ }^{12}$

Pengumpulan data responden dilakukan dengan cara wawancara terstuktur, pengukuran kadar Hemoglobin menggunakan metode cyanmethemoglobin di lakukan di 5 (lima) puskesmas dan 2 (dua) puskesmas dengan menggunakan metode autoanalyzer. Pemeriksaan haemoglobin pada kelompok perlakuan dilakukan sebelum dan sesudah perlakuan, sedangkan pada kelompok kontrol dilakukan pada saat awal penelitian dan akhir penelitian. analisis bivariat dengan uji independent sample T-test, Mann Whitney, Chi square, analisis multivariat dengan General Linier Model.

Penelitian ini sudah mendapat keterangan kelaikan etik (Ethical Clearence) dari Komisi Etik Penelitian Fakultas Kesehatan Masyarakat Universitas Diponegoro Semarang no 70/EC/FKM/2017.

\section{HASIL PENELITIAN}

Karakteristik responden menunjukkan bahwa sebagian besar responden baik pada kelompok perlakuan maupun kontrol berumur 2035 tahun. Pendidikan responden pada kedua kelompok sebagian besar adalah lulusan SMP, 
$(43,1 \%)$ pada kelompok perlakuan dan $(31,4 \%)$ pada kelompok kontrol.

Sebagian besar pekerjaan ibu adalah ibu rumah tangga. Data karakteristik responden dapat dilihat pada tabel 1 .

Sebagian besar responden $(66,7 \%)$ patuh dalam mengkonsumsi makanan tambahan sebanyak 5 keping biskuit sehari dalam waktu sembilan puluh hari. Dikatakan patuh apabila ibu hamil KEK mengkonsumsi $>80 \%$ target yang diharapkan atau lebih dari 360 keping biskuit selama 90 hari Sebagian responden tidak patuh mengkonsumsi biskuit yaitu sebanyak (33,3\%), dengan alasan bosan $(58,8 \%)$ dan karena diberikan kepada anaknya $(41,2 \%)$.

Tingkat Kecukupan Energi (TKE) sebelum maupun sesudah diberi makanan tambahan lebih besar pada kelompok kontrol sedangkan TKP lebih besar pada kelompok perlakuan,

Sebagian besar bayi lahir dengan berat badan normal, 92,3\% pada kelompok perlakuan dan 94,1\% pada kelompok kontrol. Panjang badan lahir sebagian besar tidak pendek, 60,8\% pada kelompok perlakuan dan $64,7 \%$ pada kelompok kontrol.

Gambar 1 menunjukkan bahwa setelah pemberian makanan tambahan terdapat perbedaan Kadar Hemoglobin ibu antara kelompok perlakuan dan kelompok kontrol $(p=0,020)$.

Perbedaan peningkatan Kadar Hemoglobin antara kelompok perlakuan dan kelompok kontrol di uji dengan independent Test. Rata rata kenaikan Hemoglobin pada kelompok perlakuan $(1,29 \mathrm{gr} / \mathrm{dl})$ lebih tinggi daripada kelompok kontrol $(0,97 \mathrm{gr} / \mathrm{dl})$ dengan $\mathrm{p}=0,032$.

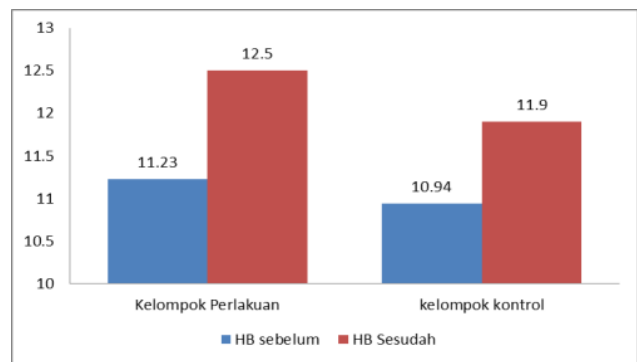

Gambar 1. Rerata Kadar Hemoglobin Ibu Sebelum dan Setelah Pemberian Makanan Tambahan Pada Kelompok Perlakuan dan Kelompok Kontrol

Gambar 2 menunjukkan bahwa terdapat perbedaan rata rata tingkat kecukupan energi (TKE) setelah pemberian makanan tambahan antara kelompok perlakuan dan kelompok kontrol $(p=0,003)$ sebelum ditambahkan energi dari biskuit. Setelah ditambahkan energi dari biskuit TKE pada kelompok perlakuan lebih tinggi daripada kelompok kontrol, $p=0,000$. Hal ini menunjukkan bahwa pemberian makanan tambahan dapat meningkatkan tingkat kecukupan energi (TKE).

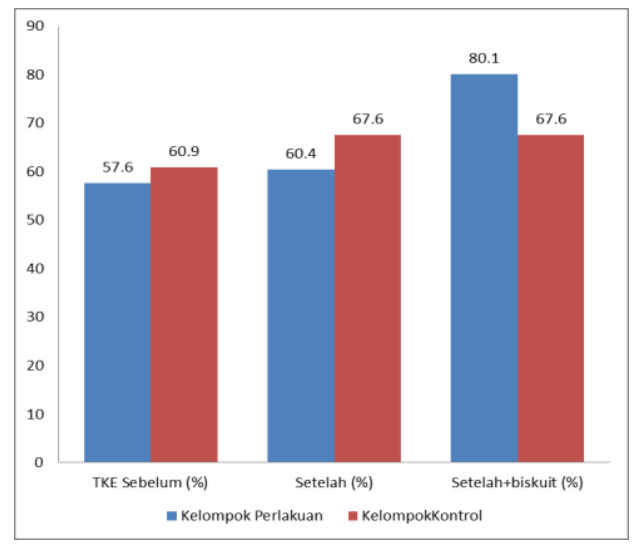

Gambar 2. Rerata Tingkat Kecukupan Energi Ibu Hamil KEK Sebelum dan Sesudah Pemberian Makanan Tambahan

Gambar 3 menunjukkan bahwa terdapat perbedaan rerata tingkat kecukupan protein antara kelompok perlakuan dan kelompok kontrol sebelum perlakuan $\quad(p=0,001)$. Setelah perlakuan, juga terdapat perbedaan TKP antara kelompok perlakuan dan kelompok kontrol $(\mathrm{p}=0,015)$. Apabila protein biskuit di perhitungkan maka mempunyai TKP jauh lebih tinggi daripada kelompok kontrol.

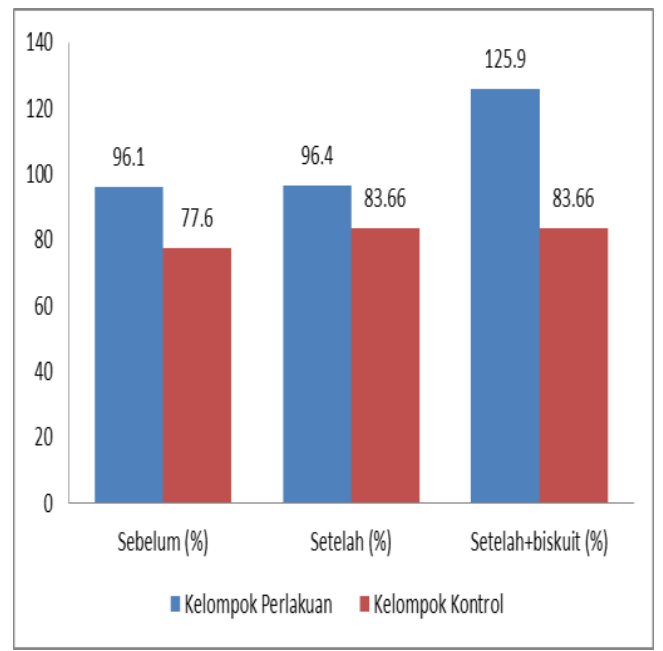

Gambar 3. Rerata Tingkat Kecukupan Protein Ibu Hamil KEK Sebelum dan Sesudah Pemberian Makanan Tambahan

Tabel 1. Krakteristik Responden umur, Pendidikan, Pekerjaan,Paritas, Gravida, Pendapatan, Umur Kehamilan dan Kadar Hemoglobin

\begin{tabular}{lll}
\hline Variabel & Kelompok Perlakuan & Kelompok Kontrol \\
\hline
\end{tabular}




\begin{tabular}{|c|c|c|c|c|}
\hline & $\mathrm{N}$ & $\%$ & $\mathrm{~N}$ & $\%$ \\
\hline \multicolumn{5}{|l|}{ Umur } \\
\hline$<20$ & 4 & 7,8 & 2 & 3,9 \\
\hline $20-35$ & 43 & 84,3 & 47 & 92,2 \\
\hline$>35$ & 4 & 7,8 & 2 & 3,9 \\
\hline \multicolumn{5}{|l|}{ Pendidikan } \\
\hline SD & 14 & 27,5 & 15 & 29,4 \\
\hline SMP & 22 & 43,1 & 16 & 31,4 \\
\hline Tamat SMA & 14 & 27,5 & 14 & 27,5 \\
\hline $\begin{array}{l}\text { Perguruan } \\
\text { Tinggi }\end{array}$ & 1 & 2,0 & 6 & 11,8 \\
\hline \multicolumn{5}{|l|}{ Pekerjaan } \\
\hline IRT & 49 & 96,1 & 43 & 84,3 \\
\hline Bekerja & 2 & 3,9 & 6 & 15,7 \\
\hline \multicolumn{5}{|l|}{ Paritas } \\
\hline$<2$ & 42 & 82,4 & 44 & 86,3 \\
\hline $2-3$ & 9 & 17,6 & 7 & 13,7 \\
\hline \multicolumn{5}{|l|}{ Gravida } \\
\hline Primigravida & 25 & 49,0 & 25 & 49,0 \\
\hline Multigravida & 26 & 51,0 & 26 & 51,0 \\
\hline \multicolumn{5}{|l|}{ Pendapatan } \\
\hline > UMR & 25 & 49,0 & 41 & 80,4 \\
\hline$<\mathrm{UMR}$ & 26 & 51,0 & 10 & 19,6 \\
\hline \multicolumn{5}{|l|}{ Umur Kehamilan } \\
\hline Trimester II & 33 & 64,7 & 36 & 70,6 \\
\hline Trimester III & 18 & 35,3 & 15 & 29,4 \\
\hline \multicolumn{5}{|l|}{$\begin{array}{l}\text { Kadar } \\
\text { Hemoglobin }\end{array}$} \\
\hline Tidak Anemi & 33 & 64,7 & 26 & 51 \\
\hline Anemi & 18 & 35,3 & 25 & 49 \\
\hline
\end{tabular}

Dilakukan uji Multivariat menggunakan General Linear Model dengan variabel dependen yaitu Kadar Hemoglobin ibu dan dikontrol dengan variabel perancu yaitu Tingkat Kecukupan Energi (TKE). Tabel. 2 menunjukkan hasil uji multivariat pengaruh pemberian makanan tambahan pada kadar Hemoglobin setelah di kontrol dengan TKE $(p=0,005)$. Bahwa pemberian makanan tambahan berpengaruh terhadap Kadar Hemoglobin ibu setelah dikontrol dengan TKE.

Tabel 2. Pengaruh Pemberian Makanan Tambahan pada Ibu Hamil Kekurangan Energi Kronis terhadap Kadar Hemoglobin Ibu Setelah di Kontrol dengan TKE

Variabel Kadar Hemoglobin

\begin{tabular}{lcc}
\hline \multicolumn{1}{c}{ kelompok } & & $(\mathrm{g} / \mathrm{dl})$ \\
\cline { 2 - 3 } & Rata-rata & $\begin{array}{l}\text { Standar } \\
\text { Error }\end{array}$ \\
\hline $\begin{array}{l}\text { Kelompok } \\
\text { Perlakuan }\end{array}$ & 12,6 & 0,198 \\
$\begin{array}{l}\text { Kelompok } \\
\text { Kontrol }\end{array}$ & 11,7 & 0,198 \\
\hline
\end{tabular}

p TKE Post $=0,056$, p kelompok $=0,005$

Tabel. 3 menunjukkan pengaruh pemberian makanan tambahan terhadap kadar Hemoglobin setelah di kontrol dengan TKP $(0,019)$

Tabel. 3 Pengaruh Pemberian Makanan Tambahan pada Ibu hamil Kekurangan Energi Kronis terhadap Kadar Hemoglobin sesudah di Kontrol dengan TKP 


\begin{tabular}{|c|c|c|}
\hline \multirow[t]{2}{*}{$\begin{array}{l}\text { Variabel } \\
\text { kelompok }\end{array}$} & \multicolumn{2}{|c|}{$\begin{array}{c}\text { Kadar Hemoglobin } \\
(\mathrm{g} / \mathrm{dl})\end{array}$} \\
\hline & Rata-rata & $\begin{array}{l}\text { Standar } \\
\text { Error }\end{array}$ \\
\hline $\begin{array}{l}\text { Kelompok } \\
\text { Perlakuan }\end{array}$ & 12,5 & 0,20 \\
\hline $\begin{array}{l}\text { Kelompok } \\
\text { Kontrol }\end{array}$ & 11,8 & 0,20 \\
\hline
\end{tabular}

TKP Pre $=0,693$ p kelompok=0,019

\section{PEMBAHASAN}

Pemberian makanan tambahan pada ibu hamil berisiko KEK diberikan pada ibu hamil dari keluarga miskin sedangkan kontrolnya adalah ibu hamil non miskin dimulai saat ibu berusia kehamilan 6 (enam) bulandan 7 (tujuh) bulan selama 90 hari.

Waktu yang tepat dalam pelaksanaan PMT sebagai program suplementasi gizi untuk ibu hamil yaitu pada trimester II dan III karena pada uasia kehamilan tersebut kebutuhan gizi meningkat dan pertumbuhan janin berjalan cepat. ${ }^{13}$

Dalam penelitian ini tidak ada perbedaan karakteristik responden antara kelompok perlakuan maupun kontrol yang meliputi umur, pendidikan, pekerjaan, jumlah anak, gravida dan umur kehamilan.

Rata rata pendapatan keluarga pada kelompok kontrol lebih tinggi dibandingkan dengan kelompok perlakuan, sehingga akan mempengaruhi pola konsumsi makanan keluarga yang berdampak pada kecukupan asupan gizi ibu. Keadaan kesehatan pada kedua kelompok sebagian besar baik sehingga asupan gizi dapat meningkatkan berat badan ibu. Peningkatan kebutuhan energi dan zat gizi ini diperlukan untuk pertumbuhan dan perkembangan janin. ${ }^{14}$

Anemia merupakan masalah gizi ibu hamil yang menyumbang permasalahan berat lahir bayi. Hal ini karena ibu yang mengalami anemi pada saat hamil akan meningkatan risiko ibu melahirkan bayi dengan BBLR. $^{15}$

Biskuit mengandung asam folat $626,86 \mathrm{mg}$ yang berperan dalam proses pembentukan sel darah merah dan untuk pendewasaan sel folat bertugas membawa karbon tunggal dalam pembentukan hem. Protein berperan penting dalam pembentukan sel darah merah dan hemoglobin, B6 berperan dalam bentuk fosforilasi piridoxin phosphate (PLP) dan piridoxamine phosphate (PMP) sebagai koenzim utama dalam transaminase, dekarboksilasi dan reaksi lain yang berkaitan dengan metabolisme protein, PLP juga berperan dalam pembentukan asam alfa aminolevulinal yaitu suatu prekusor hem dalam hemoglobin. ${ }^{16}$

Penelitian lain menunjukkan bahwa Pemberian makanan tambahan meningkatkan Kadar Hemoglobin ibu hamil berisiko KEK di Kabupaten Tanatar Sulawesi Selatan PMT yang diberikan mengandung $600-700 \mathrm{kkal}$ dan $15-20 \mathrm{~g}$ protein. PMT tersebut diberikan selama 3 bulan berturut-turut dan juga diberi $60 \mathrm{mg}$ ferrous sulfate dan $0,025 \mathrm{mg}$ asam folat. ${ }^{17}$

Pada penelitian ini biskuit sandwich yang diberikan berisi $25 \mathrm{~g}$ lemak, $15 \mathrm{gr}$ protein, $53 \mathrm{~g}$ karbohidrat, 803,27 mcg vitamin A, 626,86 mg Asam folat, $262 \mathrm{mcg}$ B12, $1,75 \mathrm{mg}$ B6 dan zat gizi lainnya. ${ }^{4} \mathrm{Hal}$ ini dapat berperan menaikan Kadar Hemoglobin.

Anemia dapat disebabkan oleh kekurangan asupan zat besi, adanya infeksi, defisiensi vitamin A, defisiensi folat, defisiensi vitamin B12, defisiensi B6, dan peningkatan kebutuhan wanita usia produktif. ${ }^{18}$

Penurunan kadar normal hemoglobin pada trimester dua kehamilan disebabkan oleh hemodilusi atau peningkatan plasma darah ibu. Wanita hamil mengalami peningkatan volume plasma hingga 45\%. ${ }^{19}$ Terdapat perbedaan peningkatan Kadar Hemoglobin pada kelompok perlakuan dan kelompok kontrol. Puncak peningkatan volume plasma terjadi pada pekan 30-34 usia kehamilan. Peningkatan volume plasma berhubungan dengan berat badan lahir. Kegagalan ekspansi volume plasma berakibat pada buruknya pertumbuhan janin. Peningkatan volume plasma disertai oleh peningkatan jumlah sel darah merah, yaitu sekitar 18\% jika ibu tidak mendapat suplementasi dan 30\% dengan suplementasi zat besi. ${ }^{20}$

Terdapat perbedaan tingkat kecukupan energi (TKE) setelah mendapat biskuit antara kelompok perlakuan dan kelompok kontrol, bahwa pemberian makanan tambahan dapat meningkatkan tingkat kecukupan energi (TKE).

Rata rata Tingkat Kecukupan Protein Ibu Hamil KEK Sebelum dan Sesudah Pemberian Makanan Tambahan pada Kelompok Perlakuan dan Kelompok Kontrol berbeda. Tingkat kecukupan protein (TKP) diperoleh melalui recall makanan 1x24 jam yang diperoleh pada pada saat sebelum mendapat makanan tambahan dan 1 x 24 jam sedang mendapat makanan tambahan.

Hasil uji independent Test menunjukkan terdapat perbedaan rerata tingkat kecukupan protein sebelum $(p=0,001)$ dan sesudah $(p=0,015)$ dan ditambah dengan biskuit $(\mathrm{p}=0,000)$ pada kelompok perlakuan dan kelompok kontrol, yang berarti bahwa ada perbedaan rata rata tingkat kecukupan protein sebelum dan sesudah dan setelah ditambah biskuit baik pada kelompok yang mendapat makanan tambahan maupun tidak mendapat makanan tambahan

Setelah di kontrol dengan Tingkat Kecukupan Energi (TKE) Pemberian makanan tambahan pada Ibu Hamil Kekurangan Energi Kronis meningkatkan Kadar Hemoglobin Ibu dengan $p$ value 0,001 dan di kontrol dengan Tingkat Kecukupan Protein (TKP) dengan $p$ value 0,004 yang berarti bahwa pemberian makanan tambahan meningkatkan Kadar Hemoglobin ibu. 
Hal ini sejalan dengan penelitian Candradewi yang menunjukkan bahwa terjadi peningkatan konsumsi zat gizi (energi, protein) pada kelompok perlakuan setelah diberikan makanan tambahan (energi 474,75 kkal dan protein sebesar 18,4 gram). ${ }^{21}$

Faktor dominan rendahnya tingkat konsumsi zat gizi diduga terjadi karena pada saat pengambilan recall makanan bertepatan dengan bulan puasa dan juga pengaruh rendahnya pendapatan.

\section{KESIMPULAN}

Pemberian Makanan Tambahan (PMT) berupa biskuit pada ibu hamil berisiko KEK di Kabupaten Tegal diberikan kepada keluarga miskin meningkatkan Kadar Hemoglobin ibu.

\section{DAFTAR PUSTAKA}

1. Dinkes Kabupaten Tegal. Profil Kesehatan Kabupaten Tegal Tahun 2015. Slawi: 2016.

2. Soemantri AG,Triasih S.(Ed.).Anemia Defiesiensi besi: epidemiology and cognitive in children with iron deficiency anemia. Yogyakarta; Medika Fakultas Kedokteran UGM; 2009

3. Direktorat Bina Gizi Masyarakat. Petunjuk Tekhnis Pemberian Makanan Tambahan ibu hamil. Jakarta: Kementerian Kesehatan Republik Indonesia; 2010

4. Keputusan Kementerian Kesehatan Republik Indonesia, nomor 899/Menkes/SK/X) 2009 Spesifikasi Teknis Makanan Tambahan Balita 25 tahun, anak usia sekolah dasar dan ibu hamil 2009 di unduh 20 Januari 2017.

5. Kementrian Kesehatan. Pedoman pemantauan Wilayah setempat kesehatan Ibu dan Anak Direktorat Bina Kesehatan Ibu. Jakarta: 2010

6. Dinkes Kabupaten Tegal. Rencana Strategis Dinas Kesehatan Kabupaten Tegal tahun 20142019. Slawi; 2015

7. Agustin Efrinita. Hubungan Antara Asupan Protein dengan Kekurangan Energi Kronis (KEK) pada ibu hamil di Kecamatan Jebres Surakarta. karyatulis ilmiah; Program Studi DIV Kebidanan Fakultas Kedokteran.Universitas Sebelas Maret: Surakarta; 2010

8. Dinkes Kab Tegal. Juknis Pemberian Makanan Tambaha Dinas Kesehatan kabupaten Tegal 2016. Dinas Kesehatan Kabupaten Tegal: Slawi; 2016

9. Jonathan S, Metode Penelitian Kuantitatif dan Kualitatif, Yogyakarta PT Graha Ilmu : 2006

10. Sudigdo s, Sofyan Ismail Dasar-Dasar Metodologi Penelitian Klinis, edisi ke-4 2011

11. Dinkes Kabupaten Tegal, Profil Kesehatan Kabupaten Tegal Tahun 2016. Slawi; 2017.

12. Zeng L, Dibley MJ, Cheng Y, Dang S, Chang S, KongL, Yan $\mathrm{H}$. Impact of micronutrient supplementation during pregnancy on birth weight, duration of gestation, and perinatal mortality in rural western China: double blind cluster randomised controlled trial. BMJ 2008;33
13. Soetjiningsih. Tumbuh Kembang Anak. Ranuh ING, editor, Jakarta: Penerbit Buku Kedokteran EGC; 1995.

14. Adriani M, Wirjatmai B. Peranan gizi dalam siklus kehidupan . Jakartra: Kencana Prenada Media Group; 2012.

15. UNICEP Indonesia . Gizi ibu dan Anak. Ringkasan kajian UNICEF Indonesia. Available from: URL:

16. Almatsier, S. Prinsip Dasar Ilmu Gizi Jakarta: Gramedia Pustaka Utama; 2010.

17. N A Taslim, dkk. Pengaruh Pemberian Makanan Tambahan dan Tablet Besi Terhadap Kadar Haemoglobin Ibu Hamil Yang Menderita Kurang Energi Kronik Di Kabupaten Takalar, Sulawesi selatan. Jurnal Med Nus: 26; 2005; (24-29)

18. Maria N, Gracia- Casal, Jose Ramirez, Irene Leets, Ana C Pereira, Maria F Qquiroga. High Iron Content and Biovailability in Humans from Four Spesies of Marine Algae. The Journal of Nutrition, 2007;137: 2691-2695.jn.nutrition,org [diakses: 5 maret 2018].

19. WHO. Promoting Optimal Fetal Development Report of a Technical Consultation. Geneva: World Health Organization; 2006

20. Achadi, EL et al. Pengukuran Status Gizi Ibu Hamil dan Ibu Menyusui dengan Metoda Antropometri. Nutrire Diaita; 2008; vol 1; no 1;49-76.

21. Chandradewi, A, ASP. Pengaruh Pemberian Makanan Tambahan Terhadap Peningkatan Berat Badan Ibu Hamil KEK di Wilayah Kerja Puskesmas Labuan Lombok. Jurusan Gizi: Poltekkes Mataram; Vol 1: 1396- 1397. 